\title{
Service-Learning Projects in Core Undergraduate Engineering Courses
}

\author{
John Duffy \\ Energy Engineering Program \\ University of Massachusetts Lowell \\ John Duffy@uml.edu \\ William Moeller \\ Professor Emeritus \\ Department of Civil Engineering \\ University of Massachusetts Lowell \\ $\underline{\text { William Moeller@uml.edu }}$ \\ David Kazmer \\ Professor \\ Department of Plastics Engineering \\ University of Massachusetts Lowell \\ David_Kazmer@uml.edu \\ Vivian Crespo \\ Graduate Student \\ Energy Engineering Program \\ University of Massachusetts Lowell \\ Vivian Crespo@student.uml.edu
}

\author{
Linda Barrington \\ Engineering Service-Learning Coordinator \\ University of Massachusetts Lowell \\ Linda Barrington@uml.edu \\ Carol Barry \\ Professor \\ Department of Plastics Engineering \\ University of Massachusetts \\ Carol Barry@uml.edu \\ Cheryl West \\ Doctoral Student \\ Department Work Environment \\ University of Massachusetts Lowell \\ Cheryl_West@student.uml.edu
}

Abstract - The College of Engineering at the University of Massachusetts Lowell (UML) has integrated service-learning (S-L) into many of its core required undergraduate courses over the last three years. Projects that meet real community needs and that help students achieve academic objectives in these core courses are percieved to be difficult to create, but, in this paper, projects for 35 different undergraduate required courses are summarized to help faculty, staff, and students develop S-L projects for their own courses. Faculty at UML were encouraged to "start small rather than not at all." Courses and projects include, for example, a first-year introduction to engineering course in which 340 students, divided into teams, designed and built moving displays illustrating various technologies for 60,000 middle school students that every year visit a history center that is part of a national park. Another example is a sophomore kinematics course in which student teams visited local playgrounds to assess their safety using deceleration, force, and impact equations learned from the course . Junior heat transfer courses focused in analyzing heat loss and making suggestions for heating system savings for a local food pantry, a city hall building, and a community mental health center, as well as for the university itself; these analyses were developed and presented to the stakeholders. Sophomore student teams from the materials course presented findings to the staff of a local textile history museum to help it begin updating its displays on recent developments in materials. Junior fluids, junior circuits, senior microprocessor, senior design of machine elements, and senior capstone design are having students design and build various parts of an automated canal lock opener for a local national park. Many of the projects are low-cost and can be implemented by individual 


\section{faculty members without the requirement of a formal institutional program. These S-L projects are integrated into a wide variety of core courses (and not just design courses) and represent typically from 10 to 20 percent of the grade.}

Index Terms - Required Courses, SLICE, Undergraduate, .

\section{INTRODUCTION}

We define service-learning as a hands-on learning approach in which students achieve academic objectives in a credit-bearing course by meeting real community needs. In engineering, the students become better professionals and better citizens while the community also benefits. There are many other definitions in the literature, for example, service-learning is the integration of academic subject matter with service to the community in credit-bearing courses, with key elements including reciprocity, reflection, coaching, and community voice in projects (Jacoby, 1996). Service-learning (S-L) has been shown to be effective in a large number of cognitive and affective measures, including critical thinking and tolerance for diversity, and leads to better knowledge of course subject matter, cooperative learning, and recruitment of underrepresented groups in engineering; it also leads to better retention of students, and citizenship (as shown below), as well as helping meet the well-known ABET EC2000 criteria (a)-(k) (ABET, 2007).

Service-learning team projects have the potential to ensure students learn and demonstrate these qualities in addition to ensuring the students have the ability to apply engineering to the design and analysis of systems and experiments. Usually, service-learning is applied in elective courses where instructors have more freedom in the topics that are covered and more freedom to decide on the time that needs to be allotted for each topic. Nevertheless, instead of adding more elective courses (just so that service-learning projects can be implemented), or instead of adding more courses to satisfy ABET requirements, it was found that S$\mathrm{L}$ projects could be incorporated into existing core courses. For example, having community partners on S$\mathrm{L}$ projects essentially guarantees that students will work on multidisciplinary teams, and that with the correct structure of S-L projects, the students will examine the impacts of engineering solutions in a societal context, both of which are ABET requirements. In the end, the idea is that S-L projects can replace traditional analytical exercises in courses and that consequently the overall workload will typically not increase for the students; if students are motivated to spend more time on S-L projects, they are free to do so and should learn more in the process.

The approach of S-L, with its roots in experiential learning, is consistent with the theories and empirical research of a number of leading educators and developmental psychologists, as documented by Brandenberger (1998) and Jacoby (1996). The approach is also consistent with the recent change in paradigm in education from a focus on teaching to a focus on learning (Brandenberger, 1998 and Jacoby, 1996). Astin et al. (2000) found with longitudinal data of 22,000 students that service participation had significant positive effects on 11 outcome measures: academic performance (GPA, writing skills, critical thinking skills), values (commitment to activism and to promoting racial understanding), self-efficacy, leadership (leadership activities, self-rated leadership ability, interpersonal skills), choice of a service career, and plans to participate in service after college. "These findings directly replicate a number of recent studies using different samples and methodologies."(Astin et al., 2000, p.ii) They found S-L to be significantly better in 8 out of 11 measures than just service without the course integration and discovered "strong support for the notion that service learning should be included in the student's major field."(Astin et al., 2000, p.iii).

Eyler and Giles (1999) included 1500 students from 20 colleges/universities in a classic study of the effect of S-L. Service-learning was found to impact positively: tolerance for diversity, personal 
development, interpersonal development, and community-to-college connections. Students reported working harder, being more curious, connecting learning to personal experience, and demonstrated deeper understanding of subject matter. The quality of placements in the community and the degree of structured reflection were found to be important in enhancing the positive effects, significantly increasing critical thinking. They found that the "students who participated in service-learning differed significantly from those who did not participate on almost every outcome we measured." (Eyler and Giles, 1999, p.182) They summed up effective S-L principles in: connection (students, peers, community, faculty; experience and analysis); continuity (all four years; reflection before, during, after service); context (messiness of community setting is integral to learning); challenge (to current perspectives; not overwhelming); and coaching (opportunity for interaction; emotional, intellectual support).

There are varied opinions in the literature regarding whether S-L projects should be required or not. Eyler and Giles (1999) state: "Service-learning is often better academic learning and thus a legitimate requirement of an academic program... Students who are most in need of the developmental opportunities afforded by service-learning may be less likely to choose such course options voluntarily" (Eyler and Giles, 1999, p. 182). In contrast, Clary, Snyder, and Stukas (1998) and Werner (1998) argue for voluntary S-L, based on research showing a required activity reduces intrinsic motivation. In addition, S-L appears to have the potential to attract and retain underrepresented populations in engineering through meaningful and experiential applications. Recent experience at Purdue indicates that voluntary S-L courses attract twice the percentage of women engineering students compared to the student engineering population (Coyle et al., 1997). Our own experience with voluntary capstone courses also indicates a similar over representation of women (in one course, there is a ratio of 4 women to 1 man over the span of 6 years) and of older and more diverse students (Duffy et al., 2008; Barrington et al., 2007).

In questionnaires prepared by Duffy (2000), of the 260 students that were surveyed (who had taken his courses from 1997 to 2004, and courses which included S-L projects) only approximately 20\% responded that they disagreed with the statement that service and academic coursework should be combined. Responses were correlated with age and gender, and showed that older students and women are more positive about the integration of service with learning. Eyler and Giles (1999) found a similar percentage on their study which included 1500 students from many disciplines.

Service-learning itself is certainly not new, and S-L in engineering is not new. Oakes (2004) in his article "Service-learning in engineering: A resource guidebook" has a list of 33 universities that have S-L in engineering and describes a number of examples of S-L. In 2004-05 the National Science Foundation (NSF) funded ten programs to introduce S-L into engineering, which would add about 8 more universities to the previous list of 33. Perhaps best known is EPICS (Engineering Projects in Community Service), which started at Purdue and now includes 17 universities. The program involves elective interdisciplinary S-L courses that students can take from first year to senior year (Coyle et al., 1997). Tsang (2000) and Lima and Oakes (2006) describe more examples of S-L in engineering courses. Most of these S-L courses are capstone or elective courses with some first-year introduction to engineering courses.

By contrast, the college of engineering at UML has integrated service-learning into many of its core required undergraduate courses over the last four years. The thesis is that 1) service-learning spread throughout the core curriculum is more effective than one intensive course, 2) a mixture of required and elective service-learning is more effective than either one or the other, and 3) service-learning could result in less coursework time than traditional programs satisfying ABET 2000 criteria. In fact, most engineering work involves initial contact with clients (here community partners) to ascertain needs and then follows with design, analysis and manufacturing of a device (or system or study) and finishing with the delivery of the device (or system or study) to the client. In other academic areas, placements in the community agencies are common; however, in engineering placements as such are not typical and generally not 
appropriate. The program at UML is called SLICE (Service-Learning Integrated throughout a College of Engineering).

Since the S-L projects are designed to not add more class or homework time for students (by replacing existing "paper" projects), projects that meet real community needs and that help students achieve academic objectives in the courses are difficult to create. Service-learning projects include direct and indirect involvement of the students with the community. Direct involvement is, of course, the ideal for the students and the community to obtain maximum benefit of learning from each other. While the goal remains to maximize the direct projects, these projects are not always practical for all the students in all the courses. For example, not all the students can travel to meet with the client, who can sometimes live outside the U.S. Sharing of experiences with other students does maximize the benefit of those students who do work directly with the community (e.g., go to Peru). Therefore, opportunities were provided for students to share with each other results and experiences, thus creating a means of reflection and of extending the benefit of the S-L project.

So far, UML has identified service-learning projects for 35 core courses in five engineering disciplines. This paper presents the types of projects that faculty successfully incorporated into their undergraduate courses.

\section{Identifying Service-Learning Projects}

A full-time permanent staff College Coordinator of Service-Learning helps faculty identify service-learning opportunities and is the main link between existing and potential community partners and faculty. The current coordinator has a background in nursing and mechanical engineering. S-L faculty coordinators in each of the College's five departments also assist faculty to identify courses within their respective departments that would be candidates for S-L projects; they also assist faculty in discovering projects and partners and help with incorporation of the project into courses. The faculty coordinators have already incorporated service-learning into some of their courses and are offered course release time of one course per semester (or a half RA) from the University.

Potential community partners enter the University from a wide range of contacts, but are typically steered to the Service-Learning Coordinator. In preliminary discussions, the Coordinator and community partner discuss the organization's goals and identify potential service-learning projects. These projects must have the potential to meet the community partner's needs, fulfill the technical objectives of targeted courses, and have a scope suitable for a one or two-semester course or courses. The Coordinator filters these projects and refers service-only projects to another office within the University. She also follows up on past projects and tries to keep continuity of projects for community partners.

The departmental S-L coordinator's role has typically been to 1) identify courses amenable to servicelearning projects and 2) persuade the faculty teaching those courses to incorporate service-learning projects. This role has required an understanding of the courses offered by the respective departments and obtaining specific objectives for those courses. Although $\$ 1000$ mini-grants (four per department per semester) and course release-time (for one member of each of the College's five departments per semester) have been offered to faculty for extra compensation, supplies, or student assistance required for the development of SL modules, these incentives have been less effective than simply having the S-L coordinators encourage the faculty to "start small rather than not at all." Graduate research assistants (one per department) have helped faculty develop course materials, have assisted faculty in implementing service learning projects, and have administered and analyzed assessment measures.

Part of the challenge in this project, however, was to sell more faculty on the effectiveness of S-L, not only to meet individual course objectives, but also to help faculty and the institution fulfill their overall missions of teaching/ learning, discovery, and engagement. This objective, along with the barrier of having 
lack of information, was addressed through faculty scholarly workgroups. The student testimonials on how S-L affected them were very popular and effective in convincing faculty about the value of S-L. In addition, a S-L website was developed to provide information to facilitate partnerships among faculty, students, and community organizations. For example, the website lists community needs, courses available for projects, examples of previous projects, contact information, background and further reading for S-L.. Approaches suggested in "The Engaged Department Toolkit," by Campus Compact were also utilized. The advice and examples of other engineering faculty, as reported in, for example, Tsang (2000) and the Campus Compact (2008) web site, also proved useful.

Table I shows the distribution of courses containing service-learning projects over the four-year undergraduate curricula of five engineering departments (chemical engineering, civil engineering, electrical engineering, mechanical and plastics engineering); the table shows the courses in which the S-L projects are required $(\bullet)$ and those which are elective $(\odot)$.

TABLE I

Distribution of COURSES With S-L By SEMESTER IN EACH Program 2005-07

\begin{tabular}{|c|c|c|c|c|c|}
\hline Year & $\mathrm{ChE}$ & $\mathrm{CE}$ & $\mathrm{EE}$ & $\mathrm{ME}$ & $\mathrm{PE}$ \\
\hline FR 1 & (†) & () & () & () & () \\
\hline FR 2 & () & () & (†) & (); & () \\
\hline SO 1 & & (;) & & () $;$ & () \\
\hline SO 2 & & & () & $(-) \odot \odot$ & (2) \\
\hline JR 1 & & (;) & () & 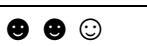 & \\
\hline JR 2 & $\odot \odot$ & () & (e) & () & () \\
\hline SR 1 & & () & () & (:) (;) (;) & \\
\hline SR 2 & & & (๑) & (;) $)$ & (-) \\
\hline Tech.Electives & $\odot$ & (๑) $\odot$ & () & 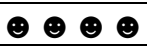 & \\
\hline
\end{tabular}

\section{INTRODUCTION TO ENGINEERING I AND II}

At UML, Introduction to Engineering I is one class of 300-400 students for all five engineering disciplines. As shown in Table II, service-learning projects have been required in this course for the past four years. Typically, the projects are worth $20-25 \%$ of the grade in the course. Introduction to Engineering II, however, is a discipline-specific course. Therefore, implementation of service-learning projects varied by department.

TABLE II

SERVICE LEARNING IN INTRODUCTION TO ENGINEERING I AND II

\begin{tabular}{|c|c|c|c|c|c|c|c|c|}
\hline & F 04 & S 05 & F 05 & S 06 & F 06 & S 07 & F 07 & S 08 \\
\hline Chemical Engineering & & $\bullet$ & \multirow{5}{*}{$\begin{array}{l}\bullet \\
\bullet \\
\bullet \\
\bullet \\
\bullet\end{array}$} & $\bullet$ & \multirow{5}{*}{$\begin{array}{l}\bullet \\
\bullet \\
\bullet \\
\bullet \\
\bullet\end{array}$} & & \multirow{5}{*}{$\begin{array}{l}\bullet \\
\bullet \\
\bullet \\
\bullet \\
\bullet\end{array}$} & \\
\hline Civil Engineering & & - & & - & & - & & - \\
\hline Electrical Engineering & & - & & - & & & & - \\
\hline Mechanical Engineering & & o & & 0 & & $\circ$ & & 0 \\
\hline Plastics Engineering & & $\bullet$ & & $\bullet$ & & $\bullet$ & & $\bullet$ \\
\hline
\end{tabular}

Introduction to Engineering I: 
Groups of freshmen have partnered with the Tsongas Industrial History Center (in 2004-06) and Zoo New England (in 2007) for required service-learning projects. A joint venture between the Lowell National Historical Park and the University of Massachusetts Lowell's Graduate School of Education, the Tsongas Industrial History Center permits primary and secondary students to learn about the American Industrial Revolution by experiencing history where it happened through hands-on activities. The learning objectives met by these projects were for the students to 1) understand the role of analysis in engineering, 2) be able to structure an engineering analysis, 3) understand the product development process, 4) be able to objectively evaluate the performance of a design, 5) be able to perform a design/ build/ test project, and 6) be able to work constructively within a team.

- In fall 2004, 80 teams of freshmen engineers designed and built Rube Goldberg devices illustrating principles of engineering for the Tsongas Industrial History Center. Eight of the educational displays were chosen to be on display in the Center, which is visited by over 60,000 school children each year.

- For the fall 2005 project, the Tsongas Industrial History Center asked teams of students to design and build models to illustrate principles of engineering mechanisms that have been employed historically in Lowell industries (e.g. waterwheels running textile mill machinery). The Tsongas displays, which were aimed at middle school students, had to include appropriate mathematical formulas and definition of critical parameters for the working model. Several of the educational displays were selected to be on display in the Center.

- The following year, approximately 354 freshmen students created working educational exhibits illustrating "energy around us" principles of engineering. The Tsongas Industrial History Center displayed the exhibits to educate K-12 students about energy.

- With a new community partner (Zoo New England) the freshmen designed and built "toys" for big cats (lions, tigers, etc.) in fall 2008. After individual students prepared preliminary designs, the classes reviewed the designs and selected the "best" for group projects. The selected designs were upgraded and presented to personnel from Zoo New England for approval. Toys were then built for approved designs and all projects meeting specifications were presented to the Zoo at the end of the semester.

With these large classes, all four projects required extensive cooperation between faculty and the community partners. Several planning sessions permitted clear definition of the objectives and constraints of the projects. The community partners presented their organization and the project to the freshmen at the starts of the project and then returned to evaluate preliminary results, assist with grading the projects, and judge projects for permanent exhibits (Tsongas Center) and testing with the big cats (Zoo New England). The Tsongas Center staff also hosted a reception for all the first-year students at the Center. Although the freshmen liked all three projects, the selection of limited number projects for exhibition at the Tsongas Center disappointed many of the students (Kazmer et al., 2007). All of the toys projects meeting specifications, however, went to the Zoo, making this project more rewarding.

In 2005, some of the freshmen also partnered with GEAR-UP (Gaining Early Awareness and Readiness for Undergraduate Programs), program that aims at increasing the number of low-income students who attend college, by interventions that raise expectations and provide support for students to succeed; this program targets 7 th graders at the Robinson, Sullivan, Rogers, Butler and Stoklosa schools in Lowell, MA. Freshmen students volunteered to present and test the design and construction of toothpick bridges, which they had studied earlier in the semester. These students presented the bridge building project and then broke into teams of one engineering student per one 7 th grader and one parent. Together each team designed a bridge out of toothpicks. All of the bridges were then tested to see which were the strongest and how they 
failed. Time for discussion was included at the end of interaction and focused upon analysis of why the 7th graders thought the failures had occurred, and what were considered the optimal design features. Everyone had such a great time that the engineering students came back again and repeated the project with another group of 7 th graders and their parents!

\section{Introduction to Engineering II:}

The focus of this course varies across the College of Engineering. In general, however, the course is used to acquaint the freshmen with their discipline and the department's faculty; teach communication skills; and start the teaching of software packages such as MATLAB and CAD packages. All of these courses include small design projects. The service-learning projects were typically worth $15-20 \%$ of the course grade and, when optional, replaced another project in the course.

- Chemical Engineering. Implementation of service-learning projects in Introduction to Engineering II has varied with the instructor and content of the course. Chemical Engineering students have partnered with the Village Empowerment Peru Project (Duffy, 2008) (a long-standing collaboration between the University and a group of Andean Villages in Peru) to create vinegar-based disinfectants for remote clinics in Peru and they have also partnered with the University's Office of Environmental Health and Safety (EHS) to raise awareness of improvements to the campus' recycling programs. In preparation for the latter project, the faculty member met with the EHS supervisor who also served as a resource for students during the S-L components and linked them with other contact people. The students researched the chemical structure of materials and their relevance to recycling; explored behind the scenes campus functions and personnel; and created posters to explain the work of the EHS and raised awareness of ways to reuse and recycle different materials on campus.

- Civil Engineering. Civil Engineering students have partnered with various organizations, including the City of Lowell (2005), the Lowell Community Health Center (2006) and the University of Massachusetts Lowell Facilities (2007-08) to redesign parking lots. In preparation for these projects, the faculty member has met with the community partners to discuss the objectives and issues associated with the redesign as well as the timeline. To start the project, the students visited the site, learned about the facility and the constraints of the project from the community partner, and measured the parking lot. For the Lowell Community Health Center, a new addition to the building would eliminate a portion of existing 48 parking spaces, but through traffic and handicapped parking locations had to be maintained in the new design. The students used these restrictions and their new skills to create 2D line and dimensioned engineering drawings of the parking lot design using AutoCAD and presented their results in a written report and oral presentation to the community partner.

- Electrical Engineering. Service-learning projects in Electrical Engineering are based on the Department's long-established assistive technology program (Assistive Technology Program, 2008). In spring 2006, 94 electrical engineering freshman constructed approximately 100 client-enabling electronic devices (big button switches) for distribution among clients with disabilities. These clients are associated with a large range of partner organizations, including the Kennedy Day School; Hogan Center, Mass Department of Mental Retardation; VA Hospital; Nashua Center; Shore Educational Collaborative; Coastal Education Collaborative; Life Links; Helping Hands; New England Education Consortium; Seven Hills; Boston Home; and the Wang Middle School Special Education Program. The students learned about the impact of such designs on the quality of life for individuals with special needs; they learned about electrical theory, technology, and application, and designed and fabricated devices. The partner organizations provided engaging on-campus 
presentations for freshman courses, describing client context and needs. The partner also provided helpful communication and feedback between student and clients (such as a Service-Learning Project Checklist) and provided reports of such projects and their related client/ organization impacts. These devices, which were designed to meet specific, and often unmet, client needs, were delivered to the partner organizations free of charge.

- Mechanical Engineering. Service-learning projects in mechanical engineering were built on previous partnerships with several science teachers at the Greater Lowell Technical High School (GLTHS). Renewable energy modules were piloted in 2005. In 2006, 13 freshmen, with the assistance of GLTHS science teachers, planned and taught renewable energy modules in 45-minute class periods; the GLTHS students later designed and tested solar ovens. For 2007, after the mechanical engineering students designed and built renewable energy projects, they developed presentations to demonstrate benefits of solar energy and explain their projects. Then three teams of freshmen delivered these presentations to the GLTHS students, introducing the high school students to the engineering discipline, helping them perform experiments with solar greenhouses and PV modules, and introducing them to the use of engineering analysis and to calculations for predicting outcomes (Bhattacharjee et al., 2008). In 2008, the format was repeated with a record 22 freshmen volunteers, enabling teams to present at both GLTHS and Lowell High School (LHS.)

- Plastics Engineering. Freshmen in Plastics Engineering have partnered with the NSF Nanoscale Science and Engineering Center - Center for High-Rate Nanomanufacturing (CHN) to develop and test nanotechnology modules used in the CHN's K12 outreach programs. To prepare for these projects, the freshmen were introduced to nanotechnology and requirements of K12 outreach modules. In 2006, the freshmen tested newly-designed middle school modules to be certain they worked as intended; and provided oral and written feedback about these modules directly to the graduate students who delivered the modules. As a result of their testing, CHN proceeded with one activity and used the students' feedback to modify another exercise. In 2007, the student groups designed, built, and presented five new modules, two of which were incorporated into middle school outreach programs in the spring of 2007.

\section{THERMOdYNAMICS, FLUIDS, AND HEAT TRANSFER COURSES}

Service-learning projects have been incorporated into thermodynamics, fluids, and heat transfer courses in several engineering disciplines. Implementation in heat transfer courses extended across chemical, mechanical, and plastics engineering (Table III). Service-learning projects in all of these courses were required and accounted for $15-20 \%$ of the course grade. In addition, a group of seniors designed an air-toair heat exchanger as part of a Thermo Applications course in mechanical engineering; this project was larger and counted for more of the course grade.

TABLE III

SERVICE LEARNING In THERMODYNAMICS, FLuids, HeAT TRANSFER COURSES

\begin{tabular}{|l|c|c|c|}
\hline & $2005-06$ & $2006-07$ & $2007-08$ \\
\hline Chemical Engineering & $\bullet$ & $\bullet$ & $\bullet$ \\
\hline Civil Engineering & & & \\
\hline Electrical Engineering & & & \\
\hline Mechanical Engineering & $\bullet \bullet$ & $\bullet \bullet \bullet \bullet$ & $\bullet \bullet \bullet \bullet$ \\
\hline Plastics Engineering & $\bullet$ & $\bullet$ & $\bullet$ \\
\hline
\end{tabular}

- mandatory; o optional 
- Chemical Engineering. A typical project is illustrated by Chemical Engineering's partnership with the Merrimack Valley Food Bank (MVFB) in 2006. In this group project, junior chemical engineering students analyzed existing heat loss problems and proposed solutions to reduce energy consumption for the MVFB, which resides in a very old building within walking distance from campus. During the winter, the building is subject to significant heat losses, while in the summertime the heat increases more than normal. Prior to starting the project, the SLICE Coordinator and faculty member visited the facility to explore heat transfer issues. MVFB personnel provided the students with utility bills and energy consumption records for a full year; conducted three facility tours to allow the students to obtain measurements needed for calculations; and were available to respond to questions via phone and e-mail during the semester. The students 1) performed a heat transfer analysis on the second floor of the warehouse where the heat problems exist, 2) proposed alterations that focused on the reduction of energy consumption, 3) performed a heat transfer analysis with the alterations to determine whether the heat transfer improved, and 4) estimated the cost of the alterations and determined the payback period of the energy consumption reduction proposed. Students presented their findings in a formal report and presentation to the MVFB directors. With lots of old buildings and rising energy prices, the analysis of energy losses in old buildings has been a good source of very useful service-learning projects. Chemical engineering students have also evaluated winter heat loss and alterations for the Mental Health Association of Greater Lowell (MHAGL) and for the United Teen Equality Center.

- Plastics Engineering. Plastics engineering students evaluated plastics insulation materials and designs for the project with the Mental Health Association of Greater Lowell; they also analyzed fresh water condensation through plastic using solar energy for remote villages in developing nations.

- Mechanical Engineering. Mechanical engineering students have examined possible window replacements for the Engineering Building of the University of Massachusetts Lowell, and also studied winter heat loss and possible alterations for the City of Lowell's JFK Civic Center. Fluids projects have also been implemented in mechanical engineering. As part of the Convective Processes course, juniors have evaluated friction loss in pipes and water supply system designs for two villages in Peru. They have also performed a hydrostatic analysis of canal locks wicket gate for the National Park Service. Seniors in an Analysis of Thermo-Fluid Processes course have analyzed heat exchanger possibilities for the Lowell's JFK Civic Center and designed drip irrigation systems for a village in Peru.

\section{MATERials Courses}

- Plastics Engineering. Plastics Engineering has a four-year history of incorporating service-learning projects in laboratories associated with sophomore-level plastics materials courses. The principle learning outcomes are the ability of students to research polymer materials, to apply their knowledge of polymer materials to a practical problem, to work in groups, and to present their work in a professional manner. Over the past three years, sophomores in Plastics Engineering have evaluated the suitability of various transparent plastic sheets for solar lanterns that will be used in Peru (for the Village Empowerment Peru Project); designed and created middle-school-level hands-on activities illustrating polymerization, the oil-to-polymer process, and alternative polymer feedstocks for the National Plastics Center's PlastiVan program; selected materials for and designed the synthetic drain layer for a green roof project proposed by the Merrimack River Watershed Council; evaluated the leeching of low-molecular-weight additives from polyvinyl chloride pipe manufactured in Peru (for 
the Peru Project); researched background and developed interactive exhibit concepts about synthetic fibers for the American Textile History Museum (Lowell, MA). For these projects, the community partner has presented the organization and the project requirements in an hour-long session with the students. The students have performed the service-learning project and then presented their results to the community partner. These projects, which are worth $20 \%$ of the course grade, replaced an experiment (and its report) and the final examination for the laboratory.

- Mechanical Engineering. In a sophomore-level materials course in Mechanical Engineering, student teams researched and presented findings to the staff of a local textile history museum to help it begin updating its displays on recent developments in materials, including electrospinning, carbon fibers, biomedical textiles, and textiles in fire fighting. On another project, the senior-level mechanical engineering laboratory students, as an optional project developed a method to test local playgrounds' surface hardness for safety.

- Chemical Engineering. Similarly, chemical engineering students have examined materials in a recycling project.

- Civil Engineering. Civil engineering students have analyzed possible materials for alleyways in partnership with the Lawrence Community Works and Groundwork Lawrence. Table IV presents the implementation of service-learning projects into materials courses.

TABLE IV

\begin{tabular}{l} 
SERVICE LEARNING IN MATERIALS COURSES \\
\begin{tabular}{|l|c|c|c|c|}
\hline & $2004-05$ & $2005-06$ & $2006-07$ & $2007-08$ \\
\hline Chemical Engineering & & $\bullet \circ$ & & \\
\hline Civil Engineering & & & $\bullet$ & \\
\hline Electrical Engineering & & & & \\
\hline Mechanical Engineering & $\circ$ & $\circ$ & $\bullet \circ$ & $\bullet \circ$ \\
\hline Plastics Engineering & $\bullet$ & $\bullet \bullet$ & $\bullet$ & $\bullet$ \\
\hline
\end{tabular} \\
\hline
\end{tabular}

\section{STATICS AND DYNAMics COURSES}

- Mechanical and Plastics Engineering. Service-learning projects were also integrated into statics, and dynamics courses (Table V). Tower designs to support water tanks used by village schools in various Peruvian towns have been extra credit (homework) projects for statics courses in mechanical and plastics engineering. The tower design projects have been worth about $10 \%$ extra that would go toward the final course grade. In another project, sophomores in a dynamics course have analyzed the safety of rides at various city playgrounds. These projects have typically been mandatory and have accounted for $20 \%$ of the course grade. Each team of two to three students visited and analyzed a different playground. The students completed analyses of playgrounds in Lowell, MA, and moved onto playgrounds in Lawrence, MA. In both courses the selected projects permit the students to apply the concepts learned during the courses to practical problems.

- Electrical Engineering. Electrical engineering students in the sophomore-level Basic EE Lab II have analyzed LEDs in headlamp designs for the Peru Project.

TABLE V

SERVICE LEARNING IN STATICS AND DYNAMICS 


\begin{tabular}{|l|c|c|c|c|}
\hline & $2004-05$ & $2005-06$ & $2006-07$ & $2007-08$ \\
\hline Chemical Engineering & & & & \\
\hline Civil Engineering & & & & $\bullet$ \\
\hline Electrical Engineering & & & $\bullet$ & \\
\hline Mechanical Engineering & $\bullet$ & $\bullet \bullet \bullet \circ$ & $\bullet \bullet \bullet \circ$ & $\bullet \circ$ \\
\hline Plastics Engineering & & $\bullet \circ$ & $\bullet \circ$ & $\circ$ \\
\hline
\end{tabular}

\section{DESIGN COURSES}

Design courses in which the objectives are the learning of design concepts and software packages for solid modeling have been a good fit for service-learning projects, particularly since the course instructors need new projects for each academic year.

- Mechanical Engineering. Sophomore-level mechanical engineering design courses have tapped the University's assistive technology program to find projects like designing a device to help a relative/friend with disabilities with everyday activities; the students partake in designing and manufacturing assistive technology devices. In the senior-level Design of Machine Elements course, the mechanical engineering students designed water towers and motorcycle ambulance connections for the Peru Project; other students designed a wicket gate mechanism for the National Park Service and some, a gym mat roller for the University's Athletics Department.

- Plastics Engineering. In plastics engineering design courses, (which are similar in structure to the sophomore-level mechanical design classes explained above), students designed and manufactured rechargeable headlamp casings for the Peru project and animal guards for high voltage transformers for National Grid customers. Nevertheless, results have been mixed for upper-level design courses: service-learning projects that meet the technical requirements of chemical engineering and plastics engineering courses have been difficult to find. The most successful product design project in that category has been an evaluation of moldable plastics grave vaults for the National Cemetery Association (the project was performed by mixed teams of seniors and graduate students).

- Electrical Engineering. First year electrical engineering students take a required introductory course in which they manufacture small electronical components to donate, such as switch testers; these are in high demand by agencies serving people with disabilities. Electrical engineering students in a junior-level Microprocessors Systems Design I course have used PIC micro-controllers to design and build monitors for human voice volume for LifeLinks and have designed and built controllers for the World's Largest Book page-turner. Juniors in Electronics I have also designed and built circuits for measuring and displaying the power generation of various water wheels for the Tsongas Industrial History Center.

- Civil Engineering. Civil and Environmental engineering juniors in the Concrete Design course were required to write a design proposal with technical drawings and mathematical analyses on the column and footing design of a proposed pedestrian bridge for a joint UML/City of Lowell project. Foundation and Soil Engineering students were broken into groups with each group reporting on a different method of bridge building given the specific conditions in the village of Yanacaca, Peru (currently accessed by a log across the river.)

TABLE VI

SERVICE LEARNING IN LOWER-LEVEL DESIGN COURSES

\begin{tabular}{|l|c|c|c|c|}
\hline & $2004-05$ & $2005-06$ & $2006-07$ & $2007-08$ \\
\hline Chemical Engineering & & & & \\
\hline
\end{tabular}




\begin{tabular}{|l|l|c|c|c|}
\hline Civil Engineering & & & & $\bullet \bullet$ \\
\hline Electrical Engineering & & & $\bullet$ & $\bullet \bullet$ \\
\hline Mechanical Engineering & $\bullet$ & $\bullet \bullet \bullet \circ$ & $\bullet \bullet \bullet \circ$ & $\bullet \circ$ \\
\hline Plastics Engineering & \multicolumn{1}{l}{$\bullet$} & $\bullet \circ$ & $\bullet \circ$ & $\bullet \bullet \bullet$ \\
\hline
\end{tabular}

\section{Capstone Projects}

Service-learning capstone projects have been implemented in Electrical, Mechanical, Civil and Interdisciplinary Engineering.

- Electrical Engineering. Electrical Engineering has a long-established assistive technology program (Assistive Technology Program 2008) in which the first capstone course requires the creation of a business plan to fund the design and development of a product which would be considered an "assistive technology" device for a specific client. In the second capstone course, the students design, test, and deliver a device that would enhance the quality of life for a person with disabilities. They are required to have direct contact with their client throughout the project.

- Mechanical Engineering. Mechanical engineering students have a selection of service-learning and industry-based capstone projects. In service-learning projects, the students have designed, built, tested, and re-designed wicket gates for a remote lock, as well as a large gate hydraulic lock-opener for the Lowell National Historical Park; they have also designed and built water supply and purification systems for whole villages, microhydro systems, prosthetic limbs, hand-powered swings and composting solar toilets for the Peru Project.

- Civil Engineering. Civil Engineering capstone students in the Spring 2008 semester designed an extension of a rail system to connect the Lowell National Park to the north campus of UML.

- Interdisciplinary Engineering. Students from other disciplines can elect an Intercollegiate Engineering Capstone Design course. These students have designed a Wi-Fi system and biodigestors for Peruvian villages and they have also created a page turner prototype for the World's Largest Book (for Groton Dunstable Regional Middle School). Students taking additional one-credit Community-based Engineering Design Projects courses have designed a W/C transfer board and trash removers for the Lowell canals.

\section{OTHER COURSES}

Service-learning projects have been introduced into other undergraduate courses.

- Civil engineering students in the junior-level Environmental Engineering Laboratory have performed road salt and chemical analyses for the Town of Dunstable. In the next semester's Water Resources Engineering course, the same students used hydrology to gain insight on chloride levels in the Town of Dunstable's wells. These projects were facilitated by a member of Dunstable's Board of Health (which oversees water quality in the wells).

- Students in various engineering statistics courses have performed statistical analyses of the survey data for the SLICE project and have analyzed crime data for the Lowell Police Department as well as analyzing health data from medical clinics that had already been fitted with radios, lights, vaccine fridges, and water pumping systems that had been installed as part of other S-L projects completed by UML students.

- In Engineering Ethics, which is required for engineering students, students have examined a number of issues related to Peruvian villages associated with the Peru Project. These issues included 
whether to provide solar-powered television systems, whether to consider opportunities for application of nanotechnology, and projects that discussed the pros and cons of nanotechnology applications.

Table VII lists the service-learning projects incorporated into graduate courses, which can be used as senior electives. The SLICE web site contains more detailed descriptions of 89 different S-L projects along with student handout examples (SLICE, 2008). Also, the appendix below has a more complete list of courses, along with the corresponding projects, into which S-L was integrated in the 2006-07 and 2007-08 academic years. Tables of courses and projects from 2004-05 and 2005-06 are presented in Duffy et al. (2007).

\section{TABLE VII}

SERVICE-LEARNING Projects In GRAduATE COURSES

\begin{tabular}{|l|l|l|}
\hline & Title & Example Projects \\
\hline \multirow{4}{*}{ CE } & $\begin{array}{l}\text { Water Resources } \\
\text { Assessment }\end{array}$ & $\begin{array}{l}\text { Water resource analysis for the National College of Forestry in Honduras } \\
\text { and El Hormiguero, Nicaragua (for Mesoamerican Development Institute) }\end{array}$ \\
\cline { 2 - 3 } & $\begin{array}{l}\text { Wastewater Treatment } \\
\text { \& Storm Water } \\
\text { Management }\end{array}$ & Wastewater technology evaluation for application in developing countries \\
\cline { 2 - 3 } & Civil Eng Lab & $\begin{array}{l}\text { Initial analysis of historical footbridge design for the Architectural } \\
\text { Heritage Foundation (Lowell, MA) }\end{array}$ \\
\hline \multirow{4}{*}{ EE } & Intro to Biosensors & Lowell HS education modules and mentoring. \\
\cline { 2 - 4 } & $\begin{array}{l}\text { Adv. Computer } \\
\text { Architecture }\end{array}$ & $\begin{array}{l}\text { Deployment and monitoring of real-time sensors for energy- use reduction } \\
\text { project of UML Facilities staff. }\end{array}$ \\
\hline \multirow{4}{*}{ ME } & $\begin{array}{l}\text { Energy Engineering } \\
\text { Workshop }\end{array}$ & $\begin{array}{l}\text { Green building upgrades for North American Indian Center of Boston; } \\
\text { solar water pumping system design and installation for Laguna, Peru; green } \\
\text { building designs for Habitat for Humanity. }\end{array}$ \\
\cline { 2 - 4 } & Energy Systems Design & $\begin{array}{l}\text { Feasibility study of photovoltaics and green building improvement for } \\
\text { Lowell Technical High School }\end{array}$ \\
\cline { 2 - 4 } & Solar Fundamentals & $\begin{array}{l}\text { Estimate solar irradiation and optimal tilt for a solar collector and install } \\
\text { system in Peru; design a solar hot water batch collector for a village biogas } \\
\text { system; design and build a solar herb crop dryer for Peru; analysis of } \\
\text { monitored weather data for design of solar systems for villages in Peru; } \\
\text { solar PV array with optimized layout for Lowell Tech HS feasibility study; } \\
\text { solar hot water systems for Indian reservation AZ. }\end{array}$ \\
\cline { 2 - 4 } & $\begin{array}{l}\text { Carbon displacement credit assessment of PV systems in Peruvian villages; } \\
\text { solar water pumping system data acquisition design and installation for } \\
\text { Peru; green building and solar designs for local teen center. }\end{array}$ \\
\cline { 2 - 4 } & $\begin{array}{l}\text { Solar Systems } \\
\text { Engineering }\end{array}$ &
\end{tabular}

\section{STUDENT AND FACULTY ACCEPTANCE}

Surveys of students and faculty have been administered in the last three academic years, 2004-07 and the instruments themselves along with results are presented in some detail in Duffy et al. (2007). Of relevance is the extent to which the projects described here have been accepted by students and faculty. Two-thirds of both groups agree in principle that service and academic coursework should be combined (i.e., servicelearning). They also agree on average that learning, teamwork, interest in subject matter, motivation to continue in engineering are all improved with S-L.

\section{Discussion}


More extensive questionnaire and interview results for both students and faculty are available in other papers (Duffy et al., 2007; Kazmer et al., 2007; Barrington et al., 2007; Bhattacharjee et al., 2008). The purpose of this paper is again to provide a more extensive description of projects incorporated into primarily engineering science courses, which is relatively rare, it appears from the literature.

There are of course tradeoffs in taking this approach. The advantages are that S-L is available to essentially all the students in the college for a significant number of semesters, that no extra courses need to be taken (saving time and money for the students) to get the benefits of S-L, that core subject matter is reinforced with the S-L projects (not just teamwork and communication), that the students are exposed to a large number of projects and community partners, that a large number of faculty are involved (increasing the benefits to them), that a significant number of community projects can be undertaken. The disadvantages compared to a program like EPICS, for example, in which extra elective courses can be taken for up to seven semesters, are that continuity of projects suffers as the students are not able to stay with work with one partner for several semesters and that multidisciplinary and interdisciplinary projects with students from different colleges and departments are much harder to implement.

Although follow up with the community partners is more challenging with this approach, locally, the College Coordinator tries to maintain a continuity of projects with the same community partners. Maintenance of hardware has not been an real issue as yet, but the projects are relatively young or are feasibility studies. The two long-term programs, Assistive Technology (ATP, 2008) and the Village Empowerment (Peru) program (Duffy, 2008), have a committed record of continuity and follow on for maintenance of systems and reanalysis and redesign of systems as well as a constant flow of projects for the community partners.

\section{CONCLUSIONS}

Although service-learning projects that meet real community needs and that help students achieve academic objectives in the courses are difficult to create, the college of engineering at UML has been able to integrate service-learning into over 35 different undergraduate core courses over the last four years. Initial projects were built on the foundation of two existing service-learning projects: the Village Empowerment Peru Project (which provides systems to remote Andean villages), and the Assistive Technology program, (which improves the lives of individuals with disabilities). New partners have been found in public schools, museums, local municipalities, and a range of community groups. Many of the projects are low-cost and can be implemented by individual faculty members without the requirement of a formal institutional program. Repeated surveys of students and faculty indicate that two-thirds of both groups agree in principle with combining service and academic coursework and agree on average that learning, teamwork, interest in subject matter, and motivation to continue in engineering are all improved with S-L.

\section{ACKNOWLEDGMENT}

The SLICE program has been supported by the volunteer efforts of many students, faculty, administrators, and community partners as well as financial support of the National Science Foundation (Grants EEC0431925 and EEC-0530632) and UML. Thanks to over 40 faculty members in engineering and other colleges who have tried S-L in their courses as part of this program.

Any opinions, findings, and conclusions or recommendations expressed in this material are those of the author(s) and do not necessarily reflect the views of the National Science Foundation. 


\section{REFERENCES}

Accreditation Board for Engineering and Technology [ABET] (2007). Criteria for accrediting engineering programs - Effective for evaluations during the 2008-2009 accreditation cycle. Retrieved February 27, 2008, from http://www.abet.org .

Assistive Technology Program (ATP). (2008). University of Massachusetts Lowell. Retrieved February 27, 2008 from http://atp.caeds.eng.uml.edu/index.html.

Astin, A., Vogelgesang, L., Ikeda, E., \& Yee, J. (2000). How service learning affects students. UCLA: Higher Education Research Institute. Retrieved March 8, 2006, from http://www.gseis.ucla.edu/heri/PDFs/HSLAS/HSLAS.pdf .

Barrington, L, \& Duffy J. (2007). Attracting underrepresented groups to engineering with service-learning. Proceedings American Society of Engineering Education Annual Conference.

Bhattacharjee, U., Lin, C., Williams, R., \& Duffy, J. (2008). Solar energy education with service-learning: Case study of a freshman engineering course. Proceedings Annual Meeting American Solar Energy Society.

Brandenberger, J.W. (1998). Developmental psychology and service-learning: A theoretical framework. In R. Bringle \& D. Duffy (Eds.), With service in mind: Concepts and models for service-learning in psychology (p. 68). Washington, DC: American Association of Higher Education.

Clary, E.G., Snyder, M., \& Stukas A. (1998). Service-learning and psychology: lessons from the psychology of volunteers' motivations. In R. Bringle and D. Duffy (Eds.), With service in mind: Concepts and models for service-learning in psychology. Washington, DC: American Association of Higher Education.

Coyle, E.J., Jamieson, L., \& Sommers, L. (1997). EPICS: A model for integrating service learning into the engineering curriculum. Michigan Journal of Community Service Learning, 4, 81-89.

Coyle, E., Jamieson, L., and Oakes, W. (2005). EPICS: Engineering projects in community service. International Journal of Engineering Education (IJEE) Vol. 21, No.1.

Duffy, J. J. (2000). Service-learning in a variety of engineering courses. In E. Tsang (Ed.), Projects that matter: Concepts and models for service-learning in engineering. Washington, DC: American Association of Higher Education.

Duffy, J., Kazmer, D., Barrington, L., Ting, J., Barry, C., Zhang, Z., Clark, D., \& Rux, A. (2007). Servicelearning integrated into existing core courses throughout a college of engineering. Proceedings American Society of Engineering Education Annual Conference.

Duffy, J. (2008). Village Empowerment: Service-learning with continuity. International Journal of Service Learning in Engineering. Vol. 3, No. 2, September. http://www.engr.psu.edu/IJSLE/home.htm.

Eyler, J., \& Giles, D. E. (1999). Where's the learning in service-learning? San Francisco, CA: Jossey-Bass. Jacoby, B., \& Assoc. (1996). Service learning in higher education. San Francisco: Jossey-Bass.

Kazmer, D., Duffy, J., Barrington, L., \& Perna, B. (2007). Introduction to engineering through servicelearning. Proceedings of the ASME 2007 International Design Engineering Technical Conferences, IDETC/DEC- 34491.

Lima, M. \& Oakes, W. (2006). Service-learning: Engineering in your community. Okemos, MI: Great Lakes Press.

Oakes, W. (2004). Service-learning in engineering: A resource guidebook. Providence, RI: Campus Compact. Retrieved March 7, 2006 from http://www.compact.org/publications/downloads/SL_and_Engineering-WEB.pdf 
SLICE: Service-Learning Integrated throughout a College of Engineering. (2008). Descriptions of 89 S-L projects. Retrieved February 28, 2008 from http://slice.uml.edu.

Tsang, E. (Ed.) (2000). Projects that matter: Concepts and models for service-learning in engineering.

Washington, DC: American Association of Higher Education.

Werner, C. (1998). Strategies for service-learning: internalization and empowerment. In R. Bringle and D. Duffy (Eds.), With service in mind: Concepts and models for service-learning in psychology.

Washington, DC: American Association of Higher Education.

\section{APPENDIX}

\begin{tabular}{|c|c|c|c|c|c|c|c|c|}
\hline \multicolumn{9}{|c|}{ Service-Learning in Courses 2006-2007 } \\
\hline & & & & & & & & \\
\hline Yr & Course \# & $\mathbf{F , S}$ & $\mathrm{Cr}$ & Course Title & Professor & Activities & S-L stu & \# stu \\
\hline \multicolumn{9}{|c|}{ Common First Year Course } \\
\hline Fr & 25.107 & F 06 & 2 & $\begin{array}{c}\text { Intro. to } \\
\text { Engineering I }\end{array}$ & $\begin{array}{l}\text { Dave } \\
\text { Kazmer }\end{array}$ & $\begin{array}{l}\text { Tsongas Industrial History } \\
\text { Center exhibits for K-12 } \\
\text { illustrating "energy around us" } \\
\text { principles of engineering; }\end{array}$ & 354 & 354 \\
\hline \multicolumn{9}{|c|}{ CORE REQUIRED COURSES } \\
\hline \multicolumn{9}{|c|}{ CHEMICAL ENGINEERING } \\
\hline $\mathrm{Jr}$ & 10.304 & S 07 & 3 & Heat Transfer & $\begin{array}{c}\mathrm{Al} \\
\text { Donatelli }\end{array}$ & $\begin{array}{l}\text { Winter heat loss/alterations } \\
\text { analysis for Mental Health } \\
\text { Assoc of Greater Lowell (MHA) }\end{array}$ & 18 & 18 \\
\hline \multicolumn{9}{|c|}{ CIVIL ENGINEERING } \\
\hline $\mathrm{Fr}$ & 25.108 & S 07 & 2 & $\begin{array}{l}\text { Intro. To Eng. } \\
\text { II - CEE }\end{array}$ & $\begin{array}{l}\text { Jackie } \\
\text { Zhang }\end{array}$ & $\begin{array}{l}\text { Parking lot re-design: UML } \\
\text { Smith \& Eames }\end{array}$ & 35 & 35 \\
\hline So & 14.286 & F 06 & 3 & $\begin{array}{l}\text { Probability \& } \\
\text { Statistics for } \\
\text { Engineers }\end{array}$ & Oz Gunes & $\begin{array}{l}\text { Statistical analysis of water } \\
\text { samples from Town of } \\
\text { Dunstable wells }\end{array}$ & 21 & 35 \\
\hline $\mathrm{Jr}$ & 14.310 & F 06 & 3 & $\begin{array}{l}\text { Engineering } \\
\text { Materials }\end{array}$ & $\begin{array}{l}\text { Krishna } \\
\text { Vedula }\end{array}$ & $\begin{array}{l}\text { Analysis of possible materials } \\
\text { for Lawrence alleyways with } \\
\text { Lawrence Community Works } \\
\text { (LCW) and Groundwork } \\
\text { Lawrence (GL) }\end{array}$ & 10 & 31 \\
\hline $\mathrm{Jr}$ & 14.332 & S 07 & 3 & $\begin{array}{l}\text { Environmental } \\
\text { Eng. Lab }\end{array}$ & $\begin{array}{c}\text { Cliff } \\
\text { Bruell }\end{array}$ & $\begin{array}{l}\text { Town of Dunstable road } \\
\text { salt/chem analysis }\end{array}$ & 27 & 27 \\
\hline $\mathrm{Sr}$ & 14.460 & F 06 & 3 & $\begin{array}{c}\text { Water } \\
\text { Resources } \\
\text { Engineering }\end{array}$ & $\begin{array}{l}\text { Jackie } \\
\text { Zhang }\end{array}$ & $\begin{array}{l}\text { Follow up on spring soils } \\
\text { project: Using hydrology to } \\
\text { gain insight on chloride levels in } \\
\text { the Town of Dunstable wells }\end{array}$ & 39 & 39 \\
\hline \multicolumn{9}{|c|}{ ELECTRICAL ENGINEERING } \\
\hline So & 16.208 & S 07 & 3 & $\begin{array}{c}\text { Basic EE Lab } \\
\text { II }\end{array}$ & Alan Rux & $\begin{array}{l}\text { LED analysis for headlamp } \\
\text { design for Peru }\end{array}$ & 36 & 36 \\
\hline $\mathrm{Jr}$ & 16.317 & F 06 & 3 & $\begin{array}{l}\text { Microprocesso } \\
\text { rs Systems } \\
\text { Design I }\end{array}$ & Yan Luo & $\begin{array}{l}\text { PIC micro controllers to build } \\
\text { monitors for human voice } \\
\text { volume for LifeLinks (North } \\
\text { Chelmsford) }\end{array}$ & 33 & 33 \\
\hline
\end{tabular}




\begin{tabular}{|c|c|c|c|c|c|c|c|c|}
\hline $\mathrm{Jr}$ & 16.317 & S 07 & 3 & $\begin{array}{l}\text { Microprocesso } \\
\text { rs Systems } \\
\text { Design I }\end{array}$ & Yan Luo & $\begin{array}{l}\text { World's Largest Book page- } \\
\text { turner control design for Groton- } \\
\text { Dunstable Regional Middle } \\
\text { School }\end{array}$ & 44 & 44 \\
\hline $\mathrm{Jr}$ & 16.365 & F 06 & 3 & Electronics I & $\begin{array}{c}\text { Joel } \\
\text { Therrien }\end{array}$ & $\begin{array}{l}\text { Designed and built circuits for } \\
\text { measuring and displaying the } \\
\text { power generation of various } \\
\text { water wheels for the Tsongas } \\
\text { Industrial History Center }\end{array}$ & 50 & 50 \\
\hline $\mathrm{Sr}$ & 16.399 & F 06 & 3 & $\begin{array}{l}\text { Capstone I } \\
\text { (Proposal) }\end{array}$ & $\begin{array}{l}\text { Alan Rux, } \\
\text { Donn } \\
\text { Clark, } \\
\text { Senait } \\
\text { Haileselas } \\
\quad \text { sie }\end{array}$ & $\begin{array}{l}\text { Develop a business plan to fund } \\
\text { the design and development of a } \\
\text { product which would be } \\
\text { considered an "Assistive } \\
\text { Technology" device. Students } \\
\text { work with a specific client and } \\
\text { identify Capstone Assistive } \\
\text { Technology project to be } \\
\text { accomplished in } 16.499 \text {. }\end{array}$ & 44 & 44 \\
\hline $\mathrm{Sr}$ & 16.399 & S 07 & 3 & $\begin{array}{l}\text { Capstone I } \\
\text { (Proposal) }\end{array}$ & $\begin{array}{l}\text { Donn } \\
\text { Clark }\end{array}$ & $\begin{array}{l}\text { Business plan to fund the design } \\
\& \text { development of Assistive } \\
\text { Technology device; incl. client }\end{array}$ & 20 & 20 \\
\hline $\mathrm{Sr}$ & 16.499 & F 06 & 3 & $\begin{array}{l}\text { Capstone II } \\
\text { (Project) }\end{array}$ & Alan Rux & $\begin{array}{l}\text { Students are required to design, } \\
\text { test and deliver a device that } \\
\text { would enhance the quality of life } \\
\text { for a disadvantaged person. } \\
\text { Students are required to have } \\
\text { direct contact with their client } \\
\text { throughout the project. }\end{array}$ & 41 & 41 \\
\hline $\mathrm{Sr}$ & 16.499 & S 07 & 3 & $\begin{array}{l}\text { Capstone II } \\
\text { (Project) }\end{array}$ & $\begin{array}{l}\text { Alan Rux, } \\
\text { Jay Fu, } \\
\text { Senait } \\
\text { Haileselas } \\
\text { sie, Chuck } \\
\text { Maffeo }\end{array}$ & $\begin{array}{l}\text { Design, test and deliver a device } \\
\text { that would enhance the quality } \\
\text { of life for a disadvantaged } \\
\text { person; including direct contact } \\
\text { with client }\end{array}$ & 50 & 50 \\
\hline \multicolumn{9}{|c|}{ MECHANICAL ENGINEERING } \\
\hline Fr & 25.108 & S 07 & 2 & $\begin{array}{l}\text { Intro. To Eng. } \\
\text { II - ME }\end{array}$ & $\begin{array}{l}\text { Sammy } \\
\text { Shina }\end{array}$ & $\begin{array}{l}\text { Renewable energy application } \\
\text { for Greater Lowell Technical } \\
\text { HS (GLTHS) }\end{array}$ & 9 & 108 \\
\hline So & 22.202 & S 07 & 2 & Design Lab II & $\begin{array}{l}\text { Bob } \\
\text { Parkin, } \\
\text { Byungki } \\
\text { Kim }\end{array}$ & $\begin{array}{l}\text { Design/manufacture of assistive } \\
\text { tech devices - for the Bill Kelly } \\
\text { Assistive Technology center at } \\
\text { the Hogan Regional Center, } \\
\text { Hathorne, MA }\end{array}$ & 53 & 60 \\
\hline So & 22.213 & S 07 & 3 & Dynamics & $\begin{array}{l}\text { Faize } \\
\text { Jamil }\end{array}$ & $\begin{array}{l}\text { Analyze playgrounds for City of } \\
\text { Lawrence, Department of Parks } \\
\text { and Recreation (and other } \\
\text { playgrounds) }\end{array}$ & 24 & 43 \\
\hline So & 22.296 & S 07 & 3 & $\begin{array}{c}\text { Mechanical } \\
\text { Behavior of } \\
\text { Materials }\end{array}$ & $\begin{array}{l}\text { Emmanuel } \\
\text { le } \\
\text { Reynaud }\end{array}$ & $\begin{array}{l}\text { Mounted posters and annotated } \\
\text { bibliographies for the American } \\
\text { Textile History Museum } \\
\text { (ATHM) }\end{array}$ & 18 & 18 \\
\hline $\mathrm{Jr}$ & 22.341 & S 07 & 3 & $\begin{array}{l}\text { Conduction \& } \\
\text { Radiation }\end{array}$ & $\begin{array}{l}\text { Hongwei } \\
\text { Sun }\end{array}$ & $\begin{array}{l}\text { Winter heat loss/alterations } \\
\text { analysis for the JFK Civic }\end{array}$ & 48 & 48 \\
\hline
\end{tabular}




\begin{tabular}{|c|c|c|c|c|c|c|c|c|}
\hline & & & & & & $\begin{array}{l}\text { Center, City of Lowell, Division } \\
\text { of Planning and Development }\end{array}$ & & \\
\hline $\mathrm{Sr}$ & 22.342 & F 06 & 3 & $\begin{array}{l}\text { Convective } \\
\text { Processes }\end{array}$ & $\begin{array}{l}\text { Gene } \\
\text { Niemi }\end{array}$ & $\begin{array}{l}\text { Piping design of water supply } \\
\text { system for Yanacaca village, } \\
\text { Peru }\end{array}$ & 47 & 47 \\
\hline $\mathrm{Jr}$ & 22.361 & F 06 & 3 & $\begin{array}{l}\text { Mathematical } \\
\text { Methods for } \\
\text { Mechanical } \\
\text { Engineers }\end{array}$ & $\begin{array}{c}\text { John } \\
\text { McKelliget }\end{array}$ & $\begin{array}{l}\text { statistical analysis of Company } \\
\text { survey for SLICE }\end{array}$ & 61 & 61 \\
\hline $\mathrm{Jr}$ & 22.381 & F 06 & 3 & Fluids & $\begin{array}{c}\text { Majid } \\
\text { Charmchi }\end{array}$ & $\begin{array}{l}\text { Canal locks wicket gate - } \\
\text { hydrostatic analysis for NPS }\end{array}$ & 11 & 48 \\
\hline $\mathrm{Sr}$ & 22.403 & F 06 & 3 & $\begin{array}{l}\text { Mechanical } \\
\text { Engineering } \\
\text { Lab II: } \\
\text { Measurement } \\
\text { Engineering }\end{array}$ & $\begin{array}{c}\text { Majid } \\
\text { Charmchi }\end{array}$ & $\begin{array}{l}\text { playground materials analysis } \\
\text { for safety }\end{array}$ & 10 & 43 \\
\hline $\mathrm{Sr}$ & 22.423 & F 06 & 3 & Capstone & $\begin{array}{l}\text { Sammy } \\
\text { Shina }\end{array}$ & $\begin{array}{l}\text { Design, build, test, re-design } \\
\text { wicket gates for remote lock for } \\
\text { the Lowell National Historical } \\
\text { Park (LNHP). }\end{array}$ & 2 & 3 \\
\hline $\mathrm{Sr}$ & 22.423 & S 07 & 3 & Capstone & $\begin{array}{l}\text { John } \\
\text { Duffy }\end{array}$ & $\begin{array}{l}2 \text { groups for Village } \\
\text { Empowerment Peru project: } \\
\text { Hand-powered swing (3) and } \\
\text { Composting solar toilet (2) }\end{array}$ & 5 & 5 \\
\hline $\mathrm{Sr}$ & 22.423 & S 07 & 3 & Capstone & $\begin{array}{l}\text { Sammy } \\
\text { Shina }\end{array}$ & $\begin{array}{l}\text { Large gate hydraulic lock } \\
\text { opener }\end{array}$ & 4 & 39 \\
\hline $\mathrm{Sr}$ & 22.425 & F 06 & 3 & $\begin{array}{l}\text { Design of } \\
\text { Machine } \\
\text { Elements }\end{array}$ & $\begin{array}{c}\text { Chris } \\
\text { Niezrecki }\end{array}$ & $\begin{array}{l}\text { Water tower designs (2) and } \\
\text { motorcycle ambulance } \\
\text { connection for Peru; wicket gate } \\
\text { mechanism for the NPS; gym } \\
\text { mat roller for UML Athletics } \\
\text { Dept. }\end{array}$ & 19 & 49 \\
\hline $\mathrm{Sr}$ & 22.441 & S 07 & 3 & $\begin{array}{l}\text { Analysis of } \\
\text { Thermo-Fluid } \\
\text { Processes }\end{array}$ & $\begin{array}{c}\text { Majid } \\
\text { Charmchi }\end{array}$ & $\begin{array}{l}\text { Analyze heat exchanger } \\
\text { possibilities for the JFK Civic } \\
\text { Center, City of Lowell, Division } \\
\text { of Planning and Development }\end{array}$ & 7 & 48 \\
\hline \multicolumn{9}{|c|}{ PLASTICS ENGINEERING } \\
\hline $\mathrm{Fr}$ & 25.108 & S 07 & 2 & $\begin{array}{l}\text { Intro. To Eng. } \\
\text { II - PE }\end{array}$ & $\begin{array}{l}\text { Carol } \\
\text { Barry, } \\
\text { Nick } \\
\text { Schott }\end{array}$ & $\begin{array}{l}\text { Teaching modules for CHN } \\
\text { Outreach program in Lowell } \\
\text { schools }\end{array}$ & 28 & 28 \\
\hline So & 26.215 & F 06 & 1 & $\begin{array}{c}\text { Plastics } \\
\text { Process Lab I }\end{array}$ & $\begin{array}{l}\text { Carol } \\
\text { Barry }\end{array}$ & $\begin{array}{l}\text { Plasticizer leaching from PVC } \\
\text { testing for Peru }\end{array}$ & 21 & 21 \\
\hline So & 26.218 & S 07 & 2 & $\begin{array}{l}\text { Intro. to } \\
\text { Design }\end{array}$ & $\begin{array}{l}\text { Steve } \\
\text { Orroth, } \\
\text { Nick } \\
\text { Schott }\end{array}$ & $\begin{array}{l}\text { Design and manufacture of } \\
\text { animal guards for high voltage } \\
\text { transformers for National Grid } \\
\text { customers }\end{array}$ & 22 & 22 \\
\hline $\mathrm{Jr}$ & 26.348 & S 07 & 3 & Heat Transfer & $\begin{array}{l}\text { "Jim" Jan } \\
\text { Chan } \\
\text { Huang } \\
\end{array}$ & $\begin{array}{l}\text { Plastic insulation analysis for } \\
\text { Mental Health Assoc of Greater } \\
\text { Lowell (MHA) }\end{array}$ & 21 & 21 \\
\hline ELE & [IVE/G] & DUA & & URSES & & & & \\
\hline
\end{tabular}




\begin{tabular}{|c|c|c|c|c|c|c|c|c|}
\hline \multicolumn{9}{|c|}{ CIVIL ENGINEERING } \\
\hline $\begin{array}{l}\mathrm{Gr} \\
\mathrm{Sr}\end{array}$ & 14.570 & S 07 & 3 & $\begin{array}{c}\text { Water } \\
\text { Resources } \\
\text { Assessment }\end{array}$ & $\begin{array}{c}\text { Bill } \\
\text { Moeller }\end{array}$ & $\begin{array}{l}\text { Water resource analysis for the } \\
\text { National College of Forestry in } \\
\text { Honduras for the Mesoamerican } \\
\text { Development Institute (MDI) }\end{array}$ & 3 & 3 \\
\hline Gr & 14.733 & S 07 & 3 & $\begin{array}{l}\text { MS Project in } \\
\text { Civil Eng Lab }\end{array}$ & $\begin{array}{l}\text { Susan } \\
\text { Faraji }\end{array}$ & $\begin{array}{l}\text { Initial analysis of historical } \\
\text { footbridge design for the } \\
\text { Architectural Hertitage } \\
\text { Foundation site at } 165 \text { Jackson } \\
\text { St. Lowell, MA }\end{array}$ & 1 & 1 \\
\hline Gr & 18.584 & S 07 & 3 & $\begin{array}{l}\text { Sustainable } \\
\text { Infrastructure } \\
\text { Practicum }\end{array}$ & $\begin{array}{c}\text { Bill } \\
\text { Moeller }\end{array}$ & $\begin{array}{l}\text { Coffee waste composting for } \\
\text { organic farmers in Honduras } \\
\text { with MDI }\end{array}$ & 1 & 1 \\
\hline \multicolumn{9}{|c|}{$\begin{array}{l}\text { ELECTRICAL ENGINEERING } \\
\end{array}$} \\
\hline $\begin{array}{l}\mathrm{Gr} \\
\mathrm{Sr}\end{array}$ & 16.541 & S 07 & 3 & $\begin{array}{l}\text { Introduction to } \\
\text { Biosensors }\end{array}$ & $\begin{array}{l}\text { XingweiXi } \\
\text { ngwei } \\
\text { Wang }\end{array}$ & $\begin{array}{l}\text { Lowell HS education modules, } \\
\text { presentation and mentoring. }\end{array}$ & 8 & 8 \\
\hline \multicolumn{9}{|c|}{ MECHANICAL ENGINEERING } \\
\hline $\mathrm{Gr}$ & 22.504 & F 06 & 3 & $\begin{array}{c}\text { Energy } \\
\text { Engineering } \\
\text { Workshop }\end{array}$ & $\begin{array}{l}\text { John } \\
\text { Duffy }\end{array}$ & $\begin{array}{l}\text { Green building upgrades for } \\
\text { North American Indian } \\
\text { Coalition of Boston }\end{array}$ & 3 & 3 \\
\hline $\mathrm{Gr}$ & 22.504 & S 07 & 3 & $\begin{array}{c}\text { Energy } \\
\text { Engineering } \\
\text { Workshop }\end{array}$ & $\begin{array}{l}\text { John } \\
\text { Duffy }\end{array}$ & $\begin{array}{l}\text { Solar water pumping system } \\
\text { design and installation for } \\
\text { Laguna, Peru }\end{array}$ & 2 & 2 \\
\hline $\begin{array}{l}\mathrm{Gr} \\
\mathrm{Sr}\end{array}$ & 22.521 & F 06 & 3 & $\begin{array}{c}\text { Solar } \\
\text { Fundamentals }\end{array}$ & $\begin{array}{l}\text { John } \\
\text { Duffy }\end{array}$ & $\begin{array}{l}\text { Estimate solar irradiation and } \\
\text { optimal tilt for a solar collector } \\
\text { and install in Yanacaca in Peru; } \\
\text { design a solar hot water batch } \\
\text { collector for a village biogas } \\
\text { system; design and build for } \\
\text { Yanacaca a solar herb crop } \\
\text { dryer. }\end{array}$ & 10 & 10 \\
\hline $\begin{array}{l}\mathrm{Gr} \\
\mathrm{Sr}\end{array}$ & 22.527 & S 07 & 3 & $\begin{array}{l}\text { Solar Systems } \\
\text { Engineering }\end{array}$ & $\begin{array}{l}\text { John } \\
\text { Duffy }\end{array}$ & $\begin{array}{l}\text { Carbon displacement credit } \\
\text { assessment of PV systems in } \\
\text { Peruvian villages with Staples; } \\
\text { solar water pumping system data } \\
\text { acquisition design and } \\
\text { installation for Huayash, Peru }\end{array}$ & 8 & 8 \\
\hline \multicolumn{9}{|c|}{ INTERCOLLEGIATE ENGINEERING } \\
\hline $\mathrm{Jr}$ & 25.300 & S 07 & 1 & $\begin{array}{c}\text { Community- } \\
\text { based } \\
\text { Engineering } \\
\text { Design Project } \\
\text { II }\end{array}$ & $\begin{array}{l}\text { Bob } \\
\text { Parkin }\end{array}$ & $\mathrm{W} / \mathrm{C}$ transfer board & 1 & 1 \\
\hline $\mathrm{Jr}$ & 25.300 & F 06 & 1 & $\begin{array}{l}\text { Community- } \\
\text { based } \\
\text { Engineering } \\
\text { Design Project } \\
\text { II }\end{array}$ & $\begin{array}{l}\text { John } \\
\text { Duffy }\end{array}$ & Lowell canals trash remover & 1 & 1 \\
\hline $\mathrm{Sr}$ & 25.400 & S 07 & 1 & $\begin{array}{c}\text { Community- } \\
\text { based }\end{array}$ & $\begin{array}{l}\text { John } \\
\text { Duffy }\end{array}$ & Lowell canals trash remover & 1 & 1 \\
\hline
\end{tabular}




\begin{tabular}{|c|c|c|c|c|c|c|c|c|}
\hline & & & & $\begin{array}{c}\text { Engineering } \\
\text { Design Project } \\
\text { III }\end{array}$ & & & & \\
\hline $\mathrm{Sr}$ & 25.401 & S 07 & 3 & $\begin{array}{l}\text { Intercollegiate } \\
\text { Engineering } \\
\text { Capstone } \\
\text { Design Project }\end{array}$ & $\begin{array}{l}\text { John } \\
\text { Duffy }\end{array}$ & $\begin{array}{l}\text { WiFi system design for } \\
\text { Huarmey Valley village in the } \\
\text { dept. of Ancash, Peru }\end{array}$ & 1 & 1 \\
\hline \multirow[t]{11}{*}{$\mathrm{Sr}$} & 25.401 & S 07 & 3 & $\begin{array}{l}\text { Intercollegiate } \\
\text { Engineering } \\
\text { Capstone } \\
\text { Design Project }\end{array}$ & $\begin{array}{c}\text { Jim } \\
\text { Sherwood }\end{array}$ & $\begin{array}{l}\text { Page turner prototype for } \\
\text { World's Largest Book for } \\
\text { Groton Dunstable Regional } \\
\text { Middle School }\end{array}$ & 4 & 4 \\
\hline & & & & & & & & \\
\hline & & & & & & & & \\
\hline & & & & & & $\begin{array}{r}\text { 2006-07 Total S-L Student- } \\
\text { Courses: }\end{array}$ & 1276 & 1613 \\
\hline & & & & & & $\begin{array}{r}\text { Total enrollment full time } \\
\text { (ABET report): }\end{array}$ & & 2154 \\
\hline & & & & & & $\begin{array}{r}\text { Total full-time regular faculty } \\
\text { with S-L: }\end{array}$ & 26 & \\
\hline & & & & & & $\begin{array}{l}\text { Total faculty with S-L } \\
\text { including part-time: }\end{array}$ & 31 & \\
\hline & & & & & & $\begin{array}{l}\text { Total faculty full-time who } \\
\text { have ever tried S-L: }\end{array}$ & 37 & \\
\hline & & & & & & $\begin{array}{r}\text { Total full-time faculty in } \\
\text { entire college: }\end{array}$ & 78 & \\
\hline & & & & & & $\begin{array}{r}\text { Total courses with students } \\
\text { engaged in S-L: }\end{array}$ & 46 & \\
\hline & & & & & & $\begin{array}{r}\text { Total required courses with } \\
\text { S-L (unique, } \\
\text { not counting sections): }\end{array}$ & 28 & \\
\hline
\end{tabular}

TABLE

COURSES WITH S-L 2007-2008

\begin{tabular}{|c|c|c|c|c|c|c|c|c|}
\hline $\mathbf{Y r}$ & Course & $\begin{array}{l}\mathrm{F}, \\
\mathrm{S}\end{array}$ & $\begin{array}{l}\mathrm{C} \\
\mathrm{r}\end{array}$ & Course Title & Professor & Activities & $\begin{array}{l}\text { \# S-L } \\
\text { stdnts }\end{array}$ & $\begin{array}{c}\text { \# of } \\
\text { stdnts }\end{array}$ \\
\hline \multicolumn{9}{|c|}{ Common First Year Course } \\
\hline $\mathrm{Fr}$ & 25.107 & $\begin{array}{c}\mathrm{F} \\
07\end{array}$ & 2 & $\begin{array}{c}\text { Intro. to } \\
\text { Engineering I }\end{array}$ & $\begin{array}{c}\text { Dave } \\
\text { Kazmer }\end{array}$ & $\begin{array}{l}\text { Design and building zoo toys to } \\
\text { reduce boredom in lion and tigers at } \\
\text { the Franklin Park Zoo for Zoo New } \\
\text { England. ( } 20 \% \text { of grade) }\end{array}$ & 380 & 380 \\
\hline \multicolumn{9}{|c|}{ CORE REQUIRED COURSES } \\
\hline \multicolumn{9}{|c|}{ CHEMICAL ENGINEERING } \\
\hline $\mathrm{Jr}$ & 10.304 & $\begin{array}{c}\mathrm{S} \\
08\end{array}$ & 3 & Heat Transfer & Al Donatelli & $\begin{array}{l}\text { Heat loss study for United } \\
\text { TeenEquality Center (UTEC) }(20 \% \\
\text { course grade) }\end{array}$ & 20 & 20 \\
\hline
\end{tabular}




\begin{tabular}{|c|c|c|c|c|c|c|c|c|}
\hline \multicolumn{9}{|c|}{ CIVIL ENGINEERING } \\
\hline $\mathrm{Fr}$ & 25.108 & $\begin{array}{c}\mathrm{S} \\
08\end{array}$ & 2 & $\begin{array}{l}\text { Intro. To Eng. } \\
\text { II - CEE }\end{array}$ & $\begin{array}{l}\text { Jackie } \\
\text { Zhang }\end{array}$ & $\begin{array}{l}\text { Pinanski Parking Lot re-design: - } \\
\text { UML Facilties Dept. ( } 30 \% \text { of course } \\
\text { grade) }\end{array}$ & 36 & 36 \\
\hline So & 14.286 & $\begin{array}{c}\mathrm{F} \\
07\end{array}$ & 3 & $\begin{array}{l}\text { Probability \& } \\
\text { Statistics for } \\
\text { Engineers }\end{array}$ & Oz Gunes & $\begin{array}{l}\text { Statistical Analysis of Chloride } \\
\text { Levels in Wells in Dunstable (in lieu } \\
\text { of worst exam) }\end{array}$ & 15 & 39 \\
\hline $\mathrm{Jr}$ & 14.332 & $\begin{array}{c}\mathrm{S} \\
08\end{array}$ & 3 & $\begin{array}{l}\text { Environmenta } \\
1 \text { Eng. Lab }\end{array}$ & Cliff Bruell & $\begin{array}{l}\text { Salt analysis for the Town of } \\
\text { Dunstable Board of Health }(12.5 \% \text { of } \\
\text { course grade) }\end{array}$ & 37 & 37 \\
\hline $\mathrm{Jr}$ & 14.350 & $\begin{array}{c}\mathrm{F} \\
07\end{array}$ & 3 & $\begin{array}{l}\text { Structural } \\
\text { Analysis I }\end{array}$ & Susan Faraji & $\begin{array}{l}\text { footbridge analysis for AHF }(5 \% \\
\text { extra credit) }\end{array}$ & 33 & 36 \\
\hline $\mathrm{Jr}$ & 14.352 & $\begin{array}{c}\mathrm{S} \\
08\end{array}$ & 3 & $\begin{array}{l}\text { Concrete } \\
\text { Design }\end{array}$ & Susan Faraji & $\begin{array}{l}\text { Pedestrian bridge column and footing } \\
\text { design for UML/City of Lowell (10\% } \\
\text { of course grade) }\end{array}$ & 33 & 33 \\
\hline $\mathrm{Sr}$ & 14.431 & $\begin{array}{c}\mathrm{F} \\
07\end{array}$ & 3 & $\begin{array}{l}\text { Foundation } \\
\text { and Soil } \\
\text { Engineering }\end{array}$ & $\begin{array}{c}\text { Sam } \\
\text { Paikowsky }\end{array}$ & $\begin{array}{l}\text { Analysis of alternative methods for } \\
\text { bridge in Yanacaca, Peru ( } 20 \% \text { of } \\
\text { grade) }\end{array}$ & 30 & 30 \\
\hline $\mathrm{Sr}$ & 14.452 & $\begin{array}{c}\mathrm{F} \\
07\end{array}$ & 3 & Steel Design & Susan Faraji & $\begin{array}{l}\text { footbridge design for AHF based on } \\
\text { analyses from } 14.350 \text { class ( } 5 \% \text { extra } \\
\text { credit) }\end{array}$ & 17 & 34 \\
\hline $\mathrm{Sr}$ & 14.460 & $\begin{array}{c}\mathrm{F} \\
07\end{array}$ & 3 & $\begin{array}{c}\text { Water } \\
\text { Resources } \\
\text { Engineering }\end{array}$ & $\begin{array}{l}\text { Jackie } \\
\text { Zhang }\end{array}$ & $\begin{array}{l}\text { Using Hydrology to Gain Insight on } \\
\text { Chloride Levels in Wells In Dunstable } \\
\text { (one homework assignment) }\end{array}$ & 27 & 27 \\
\hline $\mathrm{Sr}$ & 14.499 & $\begin{array}{c}\mathrm{S} \\
08\end{array}$ & 3 & $\begin{array}{l}\text { Capstone } \\
\text { Design }\end{array}$ & Oguz Gunes & $\begin{array}{l}\text { Trolley system design for UML, NPS, } \\
\text { City of Lowell }(100 \% \text { of course } \\
\text { grade) }\end{array}$ & 28 & 28 \\
\hline \multicolumn{9}{|c|}{ ELECTRICAL ENGINEERING } \\
\hline $\mathrm{Fr}$ & 25.108 & $\begin{array}{c}\mathrm{S} \\
08\end{array}$ & 2 & $\begin{array}{l}\text { Intro. To Eng. } \\
\text { II - EE }\end{array}$ & Jay Weitzen & $\begin{array}{l}\text { Modified a basic PS- } 2 \text { mouse and to } \\
\text { have large buttons (about } 3 \text { inches in } \\
\text { diameter) to allow severely } \\
\text { handicapped students to left and right } \\
\text { mouse click. ( } 20 \% \text { of course grade) }\end{array}$ & 130 & 130 \\
\hline $\mathrm{Fr}$ & 16.100 & $\begin{array}{c}\mathrm{F} \\
07\end{array}$ & 1 & $\begin{array}{c}\text { Intro to } \\
\text { Electrical } \\
\text { Engineering }\end{array}$ & $\begin{array}{l}\text { Xingwei } \\
\text { Wang }\end{array}$ & $\begin{array}{l}\text { Manufacturing button switch testers } \\
\text { for Assistive Tech agencies (35\% of } \\
\text { grade) }\end{array}$ & 127 & 127 \\
\hline $\mathrm{Jr}$ & 16.365 & $\begin{array}{c}\mathrm{F} \\
07\end{array}$ & 3 & Electronics I & $\begin{array}{c}\text { Joel } \\
\text { Therrien }\end{array}$ & $\begin{array}{l}\text { Design remote control for the canal } \\
\text { lock gate for the NPS ( } 15 \% \text { of grade) }\end{array}$ & 41 & 41 \\
\hline $\mathrm{Jr}$ & 16.365 & $\begin{array}{c}\mathrm{S} \\
08\end{array}$ & 3 & Electronics I & $\begin{array}{c}\text { Joel } \\
\text { Therrien }\end{array}$ & $\begin{array}{l}\text { Canal gate clicker design for the NPS } \\
\left.\text { (carry over from } 16.365 \mathrm{~F}^{\prime} 07\right)(15 \% \\
\text { of course grade) }\end{array}$ & 26 & 26 \\
\hline $\mathrm{Sr}$ & 16.399 & $\begin{array}{c}\mathrm{F} \\
07\end{array}$ & 3 & $\begin{array}{l}\text { Capstone I } \\
\text { (Proposal) }\end{array}$ & $\begin{array}{c}\text { Alan Rux, } \\
\text { Donn Clark, } \\
\text { Senait } \\
\text { Haileselassi } \\
\text { e }\end{array}$ & $\begin{array}{l}\text { Develop a business plan to fund the } \\
\text { design and development of a product } \\
\text { which would be considered an } \\
\text { "Assistive Technology" device. } \\
\text { Students work with a specific client } \\
\text { and identify Capstone Assistive } \\
\text { Technology project to be } \\
\text { accomplished in } 16.499 \text {. }\end{array}$ & 35 & 35 \\
\hline
\end{tabular}




\begin{tabular}{||c|c|c|c|c|c|l|c|c||}
\hline Sr & 16.399 & $\begin{array}{c}\mathrm{S} \\
08\end{array}$ & 3 & $\begin{array}{l}\text { Capstone } \\
\text { Proposal }\end{array}$ & Donn Clark & $\begin{array}{l}\text { Business plan to fund the design \& } \\
\text { development of Assistive Technology } \\
\text { device; incl. client (100\% of course } \\
\text { grade) }\end{array}$ & 17 & 17 \\
\hline $\mathrm{Sr}$ & 16.499 & $\mathrm{~F}$ & 3 & $\begin{array}{c}\text { Capstone II } \\
\text { (Project) }\end{array}$ & Alan Rux & $\begin{array}{l}\text { Students are required to design, test } \\
\text { and deliver a device that would } \\
\text { enhance the quality of life for a } \\
\text { disadvantaged person. Students are } \\
\text { required to have direct contact with } \\
\text { their client throughout the project. }\end{array}$ & 26 & 26 \\
$\mathrm{Sr}$ & 16.499 & $\mathrm{~S}$ & 3 & $\begin{array}{l}\text { Capstone } \\
\text { Project }\end{array}$ & Alan Rux & $\begin{array}{l}\text { Design, test and deliver a device that } \\
\text { would enhance the quality of life for a } \\
\text { disadvantaged person; including } \\
\text { direct contact with client (100\% of } \\
\text { course grade) }\end{array}$ & 24 & 24 \\
\hline
\end{tabular}

\section{MECHANICAL ENGINEERING}

\begin{tabular}{|c|c|c|c|c|c|c|c|c|}
\hline $\mathrm{Fr}$ & 25.108 & $\begin{array}{c}\mathrm{S} \\
08\end{array}$ & 2 & $\begin{array}{l}\text { Intro. To Eng. } \\
\text { II - ME }\end{array}$ & $\begin{array}{c}\text { John } \\
\text { McKelliget }\end{array}$ & $\begin{array}{l}\text { Renewable energy application for } \\
\text { Grtr Lowell Tech HS (GLTHS) and } \\
\text { Lowell High School (LHS) (30\% of } \\
\text { course grade) }\end{array}$ & 22 & 94 \\
\hline So & 22.202 & $\begin{array}{c}\mathrm{S} \\
08\end{array}$ & 2 & Design Lab II & $\begin{array}{l}\text { Byungki } \\
\text { Kim, Bob } \\
\text { Parkin }\end{array}$ & $\begin{array}{l}\text { Arm rehab device - student's } \\
\text { father( } 4) \text {, cribbage board for visually } \\
\text { impaired - student's aunt (2); } \\
\text { dosimetry rack for UML radiation lab } \\
\text { (4) ( } 25 \% \text { of course grade) }\end{array}$ & 10 & 63 \\
\hline So & 22.296 & $\begin{array}{c}\mathrm{F} \\
07\end{array}$ & 3 & $\begin{array}{c}\text { Mechanical } \\
\text { Behavior of } \\
\text { Materials }\end{array}$ & $\begin{array}{l}\text { Emmanuell } \\
\text { e Reynaud }\end{array}$ & $\begin{array}{l}5 \text { emerging materials topics for the } \\
\text { ATHM (groups of } 3,4 \text { groups per } \\
\text { topic) }\end{array}$ & 60 & 60 \\
\hline $\mathrm{Jr}$ & 22.341 & $\begin{array}{c}\mathrm{S} \\
08\end{array}$ & 3 & $\begin{array}{l}\text { Conduct'n \& } \\
\text { Radiation }\end{array}$ & $\begin{array}{l}\text { Hongwei } \\
\text { Sun }\end{array}$ & $\begin{array}{l}\text { Heat Loss windows analysis for UML } \\
\text { Facilities }\end{array}$ & 50 & 50 \\
\hline $\mathrm{Sr}$ & 22.342 & $\begin{array}{c}\mathrm{F} \\
07\end{array}$ & 3 & $\begin{array}{l}\text { Convective } \\
\text { Processes }\end{array}$ & Gene Niemi & $\begin{array}{l}\text { Design of Small Hydropower System } \\
\text { for Village of Paty, Peru ( } 20 \% \text { of } \\
\text { grade) }\end{array}$ & 45 & 45 \\
\hline $\mathrm{Jr}$ & 22.361 & $\begin{array}{c}\mathrm{F} \\
07\end{array}$ & 3 & $\begin{array}{l}\text { Mathematical } \\
\text { Methods for } \\
\text { Mechanical } \\
\text { Engineers }\end{array}$ & $\begin{array}{c}\text { John } \\
\text { McKelliget }\end{array}$ & $\begin{array}{l}\text { Impact analysis of Village } \\
\text { Empowerment Peru project } \\
\text { installations on Casma and Huarmey } \\
\text { ( } 5 \% \text { of grade) }\end{array}$ & 65 & 65 \\
\hline $\mathrm{Jr}$ & 22.381 & $\begin{array}{c}\mathrm{F} \\
07\end{array}$ & 3 & Fluids & $\begin{array}{c}\text { Majid } \\
\text { Charmchi }\end{array}$ & $\begin{array}{l}\text { Design irrigation system to supply } \\
\text { water to } 100 \text { avocado trees in the rural } \\
\text { community of Laguna, Huarmey, } \\
\text { Peru. }\end{array}$ & 12 & 50 \\
\hline $\mathrm{Sr}$ & 22.423 & $\begin{array}{c}\mathrm{S} \\
08\end{array}$ & 3 & $\begin{array}{l}\text { Capstone } \\
\text { Design }\end{array}$ & John Duffy & $\begin{array}{l}\text { modular BR unit for Arizona Indian } \\
\text { Res. ( } 100 \% \text { of course grade) }\end{array}$ & 4 & 40 \\
\hline $\mathrm{Sr}$ & 22.425 & $\begin{array}{c}\mathrm{F} \\
07\end{array}$ & 3 & $\begin{array}{l}\text { Design of } \\
\text { Machine } \\
\text { Elements }\end{array}$ & $\begin{array}{c}\text { Chris } \\
\text { Niezrecki }\end{array}$ & $\begin{array}{l}\text { World's Largest Book Page Turner for } \\
\text { GDRMS; }\end{array}$ & 4 & 44 \\
\hline $\mathrm{Sr}$ & 22.442 & $\begin{array}{c}\mathrm{S} \\
08\end{array}$ & 3 & $\begin{array}{c}\text { Thermo } \\
\text { Applications }\end{array}$ & $\begin{array}{l}\text { Hongwei } \\
\text { Sun }\end{array}$ & $\begin{array}{l}\text { Air-to-air heat exchanger design for } \\
\text { the Pollard Library, City of Lowell } \\
\text { ( } 10 \% \text { of course grade) }\end{array}$ & 42 & 42 \\
\hline
\end{tabular}

PLASTICS ENGINEERING 


\begin{tabular}{|c|c|c|c|c|c|c|c|c|}
\hline $\mathrm{Fr}$ & 25.108 & $\begin{array}{c}\mathrm{S} \\
08\end{array}$ & 2 & $\begin{array}{l}\text { Intro. To Eng. } \\
\text { II - PE }\end{array}$ & Carol Barry & $\begin{array}{l}\text { Nano outreach project for schools } \\
\text { (14.3\% of course grade) }\end{array}$ & 34 & 34 \\
\hline So & 26.215 & $\begin{array}{l}\mathrm{F} \\
07\end{array}$ & 1 & $\begin{array}{c}\text { Plastics } \\
\text { Process Lab I }\end{array}$ & Carol Barry & $\begin{array}{l}\text { education modules on polymer } \\
\text { materials for the ATHM ( } 20 \% \text { of } \\
\text { course grade) }\end{array}$ & 24 & 24 \\
\hline So & 26.218 & $\begin{array}{c}\mathrm{S} \\
08\end{array}$ & 2 & $\begin{array}{l}\text { Intro. to } \\
\text { Design }\end{array}$ & $\begin{array}{c}\text { Steve } \\
\text { Orroth, } \\
\text { Nick Schott }\end{array}$ & $\begin{array}{l}\text { Water filter designs for PET bottles } \\
\text { for VE Peru Project }\end{array}$ & 26 & 26 \\
\hline $\mathrm{Jr}$ & 26.373 & $\begin{array}{l}\mathrm{S} \\
08\end{array}$ & 3 & $\begin{array}{l}\text { Plastics Mold } \\
\text { Engineering I }\end{array}$ & $\begin{array}{l}\text { David } \\
\text { Kazmer, } \\
\text { Steve } \\
\text { Johnston }\end{array}$ & $\begin{array}{l}\text { Googleplex connectors mold for the } \\
\text { Tsongas Industrial History Center }\end{array}$ & 21 & 21 \\
\hline $\mathrm{Sr}$ & 26.415 & $\begin{array}{l}\mathrm{F} \\
07\end{array}$ & 3 & $\begin{array}{l}\text { Capstone } \\
\text { Design }\end{array}$ & Nick Schott & $\begin{array}{l}\text { New manufacturing line of hard } \\
\text { plastic ice packs for Employ+Ability }\end{array}$ & 3 & 20 \\
\hline $\mathrm{Sr}$ & 26.416 & $\begin{array}{c}\mathrm{S} \\
08\end{array}$ & 3 & Capstone II & Nick Schott & $\begin{array}{l}\text { Manufacturing line coldpack design } \\
\text { for Employ+Ability ( } 100 \% \text { of course } \\
\text { grade) }\end{array}$ & 2 & 19 \\
\hline
\end{tabular}

\section{ELECTIVE/GRADUATE COURSES}

\begin{tabular}{|c|c|c|c|l|l|l|c|c|}
\hline \multicolumn{2}{|l|}{ CIVIL ENGINEERING } \\
\hline $\begin{array}{c}\text { Sr, } \\
\text { Gr }\end{array}$ & 14.555 & $\begin{array}{c}\text { S } \\
\text { E }\end{array}$ & 3 & $\begin{array}{l}\text { Advanced } \\
\text { Structural } \\
\text { Design }\end{array}$ & Susan Faraji & $\begin{array}{l}\text { Advanced design and analysis of two- } \\
\text { way slab building construction } \\
\text { including columns and beams for } \\
\text { proposed North Campus student } \\
\text { union/ trolley terminal for UML } \\
\text { Administration (20\% of course grade) }\end{array}$ & 18 & 18 \\
\hline Gr & 14.733 & $\mathrm{~F}$ & 3 & $\begin{array}{l}\text { Directed } \\
\text { Study } \\
\text { graduate } \\
\text { Structures } \\
\text { project }\end{array}$ & Susan Faraji & $\begin{array}{l}\text { Analysis of building supports for } \\
\text { fitness equipment area for UTEC } \\
(100 \% \text { of course grade })\end{array}$ & 1 & 2 \\
\hline
\end{tabular}

\section{ELECTRICAL ENGINEERING}

\begin{tabular}{|c|c|c|c|c|c|l|c|c|}
\hline Sr & 16.409 & $\mathrm{~F}$ & 3 & $\begin{array}{c}\text { Directed } \\
\text { Study }\end{array}$ & Yan Luo & $\begin{array}{l}\text { Design of a Control System for the } \\
\text { World's Largest Book Page Turner for } \\
\text { Groton Dunstable Regional Middle } \\
\text { School (GDRMS) } 100 \% \text { of grade }\end{array}$ & 2 & 2 \\
\hline
\end{tabular}

\section{MECHANICAL ENGINEERING}

\begin{tabular}{|c|c|c|c|c|c|l|c|c|}
\hline \multicolumn{2}{|c|}{ MECHANICAL ENGINEERING } \\
\hline Gr & 22.504 & $\begin{array}{c}\mathrm{F} \\
07\end{array}$ & 3 & $\begin{array}{c}\text { Energy } \\
\text { Engineering } \\
\text { Workshop }\end{array}$ & John Duffy & $\begin{array}{l}\text { Habitat for Humanity Green Building } \\
\text { analysis (100\% of course grade) }\end{array}$ & 2 & 2 \\
\hline $\mathrm{Gr}$ & 22.521 & $\mathrm{~F}$ & 3 & $\begin{array}{c}\text { Solar } \\
\mathrm{Sr}\end{array}$ & John Duffy & $\begin{array}{l}\text { Solar hot water system design and } \\
\text { solar hot water collector design for } \\
\text { Tohono O'odham;(20\% of course } \\
\text { grade) }\end{array}$ & 11 & 11 \\
\hline
\end{tabular}




\begin{tabular}{|c|c|c|c|c|c|c|c|c|}
\hline $\mathrm{Gr}$ & 22.527 & $\begin{array}{c}\mathrm{S} \\
08\end{array}$ & 3 & $\begin{array}{l}\text { Solar Systems } \\
\text { Eng }\end{array}$ & John Duffy & $\begin{array}{l}\text { PV battery charging station for Paty, } \\
\text { Peru; PV water pumping system for } \\
\text { the Tohono O'odham reservation; PV } \\
\text { lighting system for UML; PV lighting } \\
\text { system for Lowell National Historical } \\
\text { Park; Teaching modules schools in } \\
\text { Peru; PV design for large composter } \\
\text { at UML. (20\% of course grade) }\end{array}$ & 15 & 15 \\
\hline \multicolumn{9}{|c|}{ PLASTICS ENGINEERING } \\
\hline $\begin{array}{c}\mathrm{Gr} / \\
\mathrm{Sr}\end{array}$ & 26.518 & $\begin{array}{c}\mathrm{S} \\
08\end{array}$ & 3 & $\begin{array}{l}\text { Plastics } \\
\text { Product } \\
\text { Design } \\
\end{array}$ & Nick Schott & $\begin{array}{l}\text { Solar panel shipping corners for VE } \\
\text { Peru Project ( } 20 \% \text { of course grade) }\end{array}$ & 28 & 36 \\
\hline \multicolumn{9}{|c|}{$\begin{array}{l}\text { INTERDISCIPLINARY } \\
\text { ENGINEERING }\end{array}$} \\
\hline So & 25.200 & $\begin{array}{c}\mathrm{F} \\
07\end{array}$ & 1 & $\begin{array}{l}\text { Community- } \\
\text { based } \\
\text { Engineering } \\
\text { Project I }\end{array}$ & $\begin{array}{l}\text { Byungki } \\
\text { Kim }\end{array}$ & $\begin{array}{l}\text { Improving a special chair for a } \\
\text { disabled child for the Hogan Regional } \\
\text { Center }\end{array}$ & 2 & 2 \\
\hline \multirow[t]{2}{*}{$\mathrm{Sr}$} & 25.401 & $\begin{array}{c}\mathrm{F} \\
07\end{array}$ & 3 & $\begin{array}{c}\text { Capstone } \\
\text { Community- } \\
\text { based } \\
\text { Engineering } \\
\text { Design } \\
\text { Project } \\
\end{array}$ & John Duffy & $\begin{array}{l}\text { Biodigester as Civil \& Env. } \\
\text { engineering project for Peru }\end{array}$ & 2 & 2 \\
\hline & & & & & & $\begin{array}{r}\text { Total 2007-08 Total S-L Student- } \\
\text { Courses }\end{array}$ & 1587 & 1913 \\
\hline
\end{tabular}

